\title{
Beden Ĕgitimi ve Spor Öğretmenlerinin Mesleki Etik ve Mesleki Motivasyon Durumlarının İncelenmesi: Muş İli Örneği
}

\section{Examining the Professional Ethics and Professional Motivation Levels of Physical Education and Sports Teachers: Muş Province Example}

\author{
Metin Karayol, ${ }^{\mathrm{a}, *}$ Sultan Yavuz Eroğlu ${ }^{\mathrm{b}}$ \\ ${ }^{a}$ Dr. Öğr. Üyesi, Muş Alparslan Üniversitesi, Beden Eğitimi ve Spor Yüksekokulu, Spor Yöneticiliği Bölümü, 49100, Muş/Türkiye. \\ ORCID: 0000-0003-0809-0410

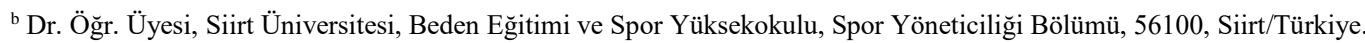 \\ ORCID: 0000-0001-5875-2836
}

\begin{tabular}{|c|c|}
\hline MAKALE BİLGİSİ & ÖZ \\
\hline $\begin{array}{l}\text { Makale Geçmişi: } \\
\text { Başvuru tarihi: } 31 \text { Ocak } 2020 \\
\text { Düzeltme tarihi: } 26 \text { Şubat } 2020 \\
\text { Kabul tarihi: } 01 \text { Mart } 2020\end{array}$ & $\begin{array}{l}\text { Bu araştırmanın amacı, beden eğitimi ve spor öğretmenlerinin mesleki etik ve mesleki motivasyon durumlarını } \\
\text { incelemektir. Araştırma nicel bir çalışma olup çalışmada ilişkisel tarama modeli kullanılmıştır. Araştırmanın } \\
\text { evrenini Muş İl Milli Eğitim Müdürlügu'nde çalışan beden eğitimi ve spor öğretmenleri oluştururken, örneklem } \\
\text { grubunu ise kolaylama örnekleme yöntemi ile belirlenen Muş Merkez'de görev yapan } 20 \text { kadın } 104 \text { erkek } \\
\text { toplamda } 124 \text { beden eğitimi ve spor öğretmeni oluşturmaktadır. Örneklem grubuna araştırmacılar tarafından } \\
\text { oluşturulan kişisel bilgi formu, beden eğitimi öğretmeni ' 'Mesleki Etik Ölçeği', ve beden eğitimi öğretmenleri } \\
\text { için ' 'Mesleki Motivasyon Ölçeği', uygulanmıştır. Yapılan analiz sonuçlarına göre mesleki etik ve mesleki } \\
\text { motivasyon alt boyutlarının cinsiyet, medeni durum, çalışılan okul, öğretmenlik kidemi ve idari görev değişkeni } \\
\text { ile arasında anlamlı bir fak saptanmamıştır. Veli ve Öğrencilerden kaynaklanan Motivasyon, Mesleki sorumluluk } \\
\text { ve mesleki etik genel alt boyutlarının yaş değişkeni ile arasında anlamlı bir fark saptanmıştır. Mesleki etik ile } \\
\text { mesleki motivasyon alt boyutları arasında pozitif ve negatif korelasyon görülmüştür. Regresyon analizine göre } \\
\text { mesleki etik ve mesleki sorumluluk alt boyutlarının mesleki motivasyon genel düzeyini arttırdı̆ğ görülmüştür. }\end{array}$ \\
\hline
\end{tabular}

\section{A R T I CLE INFO}

\section{Article history:}

Received 31 January 2020

Received in revised form 26 Şubat 2020

Accepted 01 March 2020

\section{Keywords:}

Physical Education and Sports

Ethics

Motivation

Sports Management

\section{A B S TR A C T}

The aim of this study is to examine the professional ethics and professional motivation levels of physical education and sports teachers. The research is a qualitative study conducted with the correlational survey model. The population of the study is comprised of the physical education and sports teachers working under Muş provincial directorate of national education, and the sample group is comprised of 124 physical education and sports teachers (20 females and 104 males), who were selected through the convenience sampling method and working in central Muş. The Personal Information Form that was prepared by the researchers, 'Professional Ethics Scale" for the physical education teachers, and "Professional Motivation Scale" for the physical education teachers were administered to the sample group. According to the results of the analyses, it was determined that there was statistically no significant difference between the sub-dimensions of professional ethics and professional motivation and the variables of gender, marital status, the school of the teacher, teaching experience, and administrative task. On the other hand, a statistically significant difference was determined between the age variable and the sub-dimensions of motivation, professional responsibility, and professional ethics that are parent and student oriented. Additionally, it was determined that there were positive and negative correlations between the professional ethics and professional motivation sub-dimensions. Based on the regression test, it was observed that professional ethics and professional motivation sub-dimensions increased the general level of professional motivation.

\section{Giriş}

Spor, yaşam içerisinde bireylerin bedensel, ruhsal ve zihinsel olarak sağlıklı ve iyi olmaları için yaptıkları, dayanışma ve kaynaşmanın hedeflendiği fiziksel etkinlikler bütünüdür (Eroğlu ve Ersoy, 2019; Eroğlu ve Acet, 2017; Murathan, 2018). Ayrıca beden eğitimi ve sporun alan yazında kabul görmüş pek çok faydasının yazıldığı bilinmektedir. Sporun

\footnotetext{
* Sorumlu yazar/Corresponding author

e-posta: m.karayol@alparslan.edu.tr
} 
toplum içerisinde faydaları psikolojik, sosyolojik, fiziksel, fizyolojik ve ruhsal olarak karşımıza çıkmaktadır (Aygün, 2019; Eroğlu, 2019). Öğrenme ve öğretme faaliyetleri insanoğlunun yeryüzünde var olmasıyla başlayan ve evrendeki yaşamının sonlanmasıyla bitecek olan uzun bir süreçtir (Murathan ve Özdemir, 2017). Bu nedenle çok yönlü bir yapıya sahip olan sporun içerisinde yetişen bireyler, üniversitelerin beden eğitimi ve spor fakültelerinden mezun olduktan sonra öğretmenlik mesleğini, topluma faydalı bireyler yetiştirmek için gerek okul içerisinde gerekse de okul dişında yapmaktadırlar.

Eğitim sisteminin en önemli parçası olan öğretmenlik branşı günümüzde de büyük önem arz etmektedir. Öğretmenlik mesleğini tercih eden kişilerin sürekli muhatap alacakları öğrencilere karşı, yeterli duyarlılık seviyesine sahip olmaları beklenmektedir. $\mathrm{Bu}$ duyarlılık durumu kişilerin bireysel özellikleri ile bağlantılı ve ruh sağlık durumlarını önemi derece etkilemektedir. Çünkü öğretmenlik branşı, işin sadece maddiyata dayandığı bir meslek grubu değildir. Öğretmenler, psiko-sosyal doyum ve gelişim yakalamak için de bu branşı sürdürmektedir (Ayık ve Ataş, 2014). Öğretmenlik branşında kendini tamamlamak için bazı etkenlere sahip olmak gerekmektedir. Bu etkenlerin başında motivasyon gelmektedir. Bireyler amaçlarına, ihtiyaçlarına ve içgüdülerine ulaşmak için yeterli motivasyonu kazanmaları gerekmektedir. Kazanılan bu motivasyon insanların mesleklerini başarıyla tamamlamalarına olanak sağlamaktadır. Buna göre motivasyon, insanların davranışlarının arkasındaki nedenleri tanımlar. Motive edilmiş davranışlar enerjik, odaklanılmış ve kalıcıdır (Amrai, Motlagh, Zalani, \& Parhon, 2011). Motivasyon bir dürtü olarak veya belirli bir eylem veya davranış olarak tanımlanabilir (Brouse, Basch, LeBlanc, McKnight, \& Lei, 2010). Temel motivasyon kavramının, bir örgüt, kurumda çalışan personel ya da işletme açısından ele alınması ise mesleki motivasyon kavramıdır. Mesleki motivasyon, herhangi bir yerde çalışan kişilerin belirli bir görev ya da işi amacına ya da manevi ve maddi ödüle ulaşmaya dönük olarak göstermiş olduğu çaba ve gerçekleştirdiği davranışların yer aldığı psikolojik bir süreçtir (Çarıkçı ve Zeynel, 2015). Bu süreç içerisinde, bireylerin eylemleri etik değerlerle yakından ilişkili olduğu görülmektedir. $\mathrm{Bu}$ bağlamda etik kavramını ele alacak olursak; etik, insanın kişisel ve toplumsal yaşamındaki ahlaki sorunlarını incelemektedir. Etik kavramını daha kapsamlı bir şekilde ele alınmış ve etiği "Belli bir yaşama idealini hayata geçirebilmek için mücadele eden, çağı ve üyesi olduğu toplumun yaşayışını eleştiren, hatta mahkûm eden, mevcut değerler silsilesi yerine alternatif değerleri koyan, yaşama kurallarını açık seçik tanımlayan, kısaca hayata anlam katan ahlaki ilkeler teorisi, felsefe disiplini" şeklinde ifade etmiştir (Cevizci, 2002). Öğretmenlik mesleği etik davranışları içerisinde profesyonellik, hizmette adalet, sorumluluk, sağlıklı ve güvenli bir ortamın sağlanması, eşitlik, dürüstlük, yolsuzluk yapmama, tarafsılık, doğruluk ve güven, saygı, mesleki bağlılık ve sürekli gelişme, kaynakların etkili kullanımı gibi davranışlar bulunmaktadır (Altınkurt ve Y1lmaz, 2011).

Eğitimin temel amacı eğitimi kullanarak nitelikli insan gücü sağlamaktır. Hem ruhsal hem de fiziksel yönden kendini geliştirmiş nitelikli insan, birlikte zaman geçirdiği toplumda sosyal ilişkileri kurma anlamında da yeterlilikleri olan kişidir. Bu manada nitelikli insan yetiştirilmesinde, sporun önemi yadsınamaz (K1zılet, 2018). Bir diğer yönden, beden eğitimi ve spor dersleri, öğrencilerin temel ve özel motor becerilerin gelişmesinde ve öğrencilerin aktif ve sağlıklı bir yaşam tarzını felsefe edinmelerinde önemli bir yere sahiptir (Kiremitçi, Boz, \& Yıldız, 2018). Beden eğitimi derslerinin önemini tamamlayan unsurlardan biriside beden eğitimi ve spor öğretmenleridir (Bayrak, Çınar, Çoban ve Çoşkuner, 2013). Toplum açısından büyük bir öneme sahip olan bir diğer öğretmenlik branşı beden eğitimi ve spor öğretmenliğinde mesleki motivasyon ve mesleki etik davranışlarının yüksek olması meslek içerisinde pozitif anlamda farklılıklarını ortaya koyan unsurlardan birkaçıdır. Alan yazında her ne kadar öğretmenlik ve akademisyenlik mesleklerine ilişkin mesleki etik ve mesleki motivasyon konuları çalışılmış olsa da beden eğitimi ve spor öğretmenleri üzerine sınırlı sayıda çalışmaya rastlanmıştır (Lee, 2005; Özen, 2017; Sakin, 2007; Uğraş, 2018). Beden eğitimi ve spor öğretmenlerinin mesleki etik ve mesleki motivasyon durumlarını inceleyen bir araştırmaya az sayıda rastlanmış olması araştırmanın gerekçelerindendir. Ayrıca yapılan birçok çalışmanın nüfus yoğunluğu fazla ve büyükşehirlerde yapılmış olması büyükşehir ve şehirlerde yaşamının getirdiği avantaj ve dezavantajlı durumların yapılacak çalışmada merak konusu oluşturarak Muş ilinin seçilmesi araştırmanın bir başka gerekçesidir. Bu gerekçeler ile beden eğitimi ve spor öğretmenlerinin kendi içlerindeki mesleki motivasyon ve mesleki etik durumlarının incelenerek bu kapsamda aşağıdaki alt problemlere cevap aranmıştır: 1. Öğretmenlerin mesleki etik alt boyutları puan ortalamaları nedir? 2. Öğretmenlerin mesleki motivasyon alt boyutları puan ortalamaları nedir? 3. Öğretmenlerin mesleki etik ve mesleki motivasyon alt boyutları arasında ilişki var mıdır? 4. Öğretmenlerin mesleki etik ve mesleki motivasyon genel düzeyleri arasında ilişki var mıdır? 5. Öğretmenlerin mesleki etik puanlarının tanımlayıcı özeliklerine göre anlamlı farklılık var mıdır? 6. Öğretmenlerin mesleki motivasyon puanlarının tanımlayıcı özeliklerine göre anlamlı farklılık var mıdır?

\section{Yöntem}

Bu bölümde, araştırmanın modeli, evren ve örneklem, veri toplama araçları, verilerin toplanması ve analizi ile ilgili bilgiler yer almaktadır.

\subsection{Araștırmanın Modeli}

Etik kurul raporu alınan ve beden eğitimi ve spor öğretmenlerinin mesleki etik ve mesleki motivasyon durumlarını incelemeyi amaçlayan, genel tarama modellerinden olan tarama modelinin uygulandığı betimsel bir araştırmadır. İlişkisel tarama modeli iki ve daha çok sayıdaki değişken arasında birlikte değişimin varlığını belirlemeyi amaçlayan tarama yaklaşımına denir. İlişkisel tarama modelinde, değişkenlerin birlikte değişip değişmediği; değişme varsa bunun nasıl olduğu saptanmaya çalışılır (Karasar, 2011).

\subsection{Evren ve Örneklem}

$\mathrm{Bu}$ araştırmanın evrenini Muş İl Milli Eğitim Müdürlüğü bünyesinde çalışan beden eğitimi ve spor öğretmeleri oluşturmaktadır. Örneklem grubunu ise kolaylama örnekleme yöntemi (Gratton, \& Jones, 2010) ile belirlenen Muş Merkez'de görev yapan beden eğitimi ve spor 
öğretmenleri oluşturmaktadır. Örneklem grubuna ait tanımlayıcı özellikler aşağıdaki tabloda verilmiştir.

Tablo 1. Tanımlayıcı Özellikler

\begin{tabular}{lcc}
\hline Gruplar & Katılımcı (n) & Yüzde (\%) \\
\hline Cinsiyet & & \\
\hline Kadın & 20 & 16,1 \\
Erkek & 104 & 83,9 \\
\hline Yaş & & \\
\hline 30 ve Altı & 86 & 69,4 \\
30 Üzeri & 38 & 30,6 \\
\hline Medeni Durum & & \\
\hline Evli & 67 & 54,0 \\
Bekar & 57 & 46,0 \\
\hline Çalışılan Okul & & 65,3 \\
\hline İlköğretim & 81 & 34,7 \\
Lise & 43 & \\
\hline Ö̆̆gretmenlik Kıdemi & 37,1 \\
\hline 2 Yıl ve Altı & 46 & 41,9 \\
3-5 Y1l & 52 & 21,0 \\
6 Y1l ve Üzeri & 26 & 19,4 \\
\hline İdari Görev Durumu & 80,6 \\
\hline Evet & 24 & \\
Hayır & 100 & \\
\hline
\end{tabular}

Tablo 1 incelendiğinde öğretmenler cinsiyete göre 20'si $(\% 16,1)$ kadın, 104'ü $(\% 83,9)$ erkek, yaşa göre 86's1 $(\% 69,4)$ 30 ve altı, 38'i $(\% 30,6) 30$ üzeri, medeni duruma göre 67'si $(\% 54,0)$ evli, 57'si $(\% 46,0)$ bekar, çalışılan okula göre 81'i $(\% 65,3) \quad$ ilköğretim, 43'ü $(\% 34,7) \quad$ lise, öğretmenlik k1demine göre 46'sı $(\% 37,1) 2$ y1l ve altı, 52'si (\%41,9) 3-5 y11, 26's1 $(\% 21,0) 6$ yıl ve üzeri, idari görev durumuna göre 24 'ü $(\% 19,4)$ evet, 100 'ü $(\% 80,6)$ hayır olarak dağılmaktadır.

\subsection{Veri Toplama Araçları}

Veri toplama aracının kullanabilmesi için katılımcıların demografik bilgilerini içeren ve uzman görüşü alınarak hazırlanmış bilgi formu oluşturulmuştur.

Beden eğitimi öğretmeni mesleki etik ölçeği; Uğraş (2018) tarafindan 2 boyuttan oluşmaktadır. Hem ortaokul hem de lisede çalışan beden eğitimi öğretmenleri için geliştirilmiştir. Ölçeğin Mesleki Sorumluluk alt boyutunu 2, 3, 4, 7, 8, 10, 16, 17, 18 ve 19. maddeleri açıklamaktadır. Mesleki Sayg1 boyutunu ise $1,5,6,9,11,12,13,14$ ve 15 . maddeleri açiklamaktadır. 8 madde $(1,5,9,11,12,13,14$ ve 15.) olumsuz (tersine) sorulardır. Ölçekte ölçme birimi olarak 5 'li likert türü ölçek "Kesinlikle Katılıyorum (5), Katılıyorum (4), Orta Düzeyde Katılıyorum (3), Katılmıyorum (2), Kesinlikle katılmıyorum (1)" kullanılmıştır. Bu araştırmada Mesleki Etik ölçeğinin güvenirliği Cronbach's Alpha=0,866 olarak bulunmuştur.

Beden eğitimi öğretmenleri için mesleki motivasyon ölçeği: Uğraş (2017) tarafından geliştirilen üç boyuttan oluşan 13 maddelik bir ölçektir. Hem ortaokul hem de lisede çalışan beden eğitimi öğretmenleri için geliştirilmiştir. Ölçeğin Okul Ortamından Kaynaklanan Motivasyon alt boyutunu 2, 3, 8 ve 13. maddeleri açıklamaktadır. Veli ve Öğrenciden Kaynaklanan Motivasyon alt boyutunu 1, 9, 10, 11 ve 12. maddeleri açıklamaktadır. İçsel Motivasyon alt boyutunu ise
4, 5, 6 ve 7. maddeleri açıklamaktadır. 5 madde $(2,3,4,8$ ve 13.madde) olumsuz (tersine) sorulardır. Ölçekte ölçme birimi olarak 5'li likert türü ölçek "Her Zaman (5), Sıklıkla (4), Bazen (3), Nadiren (2), Hiçbir zaman (1)” kullanılmıştır. $\mathrm{Bu}$ araştırmada Mesleki Motivasyon ölçeğinin güvenirliği Cronbach's Alpha=0,913 olarak bulunmuştur.

\subsection{Verilerin Toplanmas 1}

Veriler, araştırmacılar tarafından hazırlanan anketler yoluyla katılımcıların çalıştıkları okullara gidilerek 3 hafta içerisinde toplanmıştır. Katılımcılarla yüz yüze görüşülerek çalışma ile ilgili bilgilendirmeler yapılmıştır.

\subsection{Verilerin Analizi}

Araştırmada elde edilen verilerin değerlendirilmesinde tanımlayıcı istatistiksel yöntemleri olarak sayı, yüzde, ortalama, standart sapma kullanılmıştır. İki bağımsız grup arasında niceliksel sürekli verilerin karşılaştırılmasında $\mathrm{T}$ Testi, ikiden fazla bağımsız grup arasında niceliksel sürekli verilerin karşılaştırılmasında Tek Yönlü (One way) ANOVA Testi kullanılmıştır. ANOVA Testi sonrasında farklılıkları belirlemek üzere tamamlayıcı post-hoc analizi olarak Scheffe testi kullanılmıştır. Araştırmanın sürekli değişkenleri arasında Pearson Korelasyon ve Regresyon Analizi uygulanmıştır.

\section{Bulgular}

Bu bölümde, beden eğitimi ve spor öğretmenlerinin vermiş oldukları cevaplar neticesinde ölçekler yoluyla toplanan verilerden, elde edilen bulgular yer almaktadır. Elde edilen bulgulara dayalı olarak açıklama ve yorumlar yapılmıştır.

Tablo 2. Mesleki Etik Puan Ortalamaları

\begin{tabular}{llllll}
\hline & N & Ort & Ss & Min. & Mak. \\
\hline Mesleki Sorumluluk & 124 & 1,548 & 0,809 & 1,00 & 4,90 \\
\hline Mesleki Sayg1 & 124 & 3,016 & 0,765 & 1,44 & 5,00 \\
\hline Mesleki Etik Genel & 124 & 2,244 & 0,508 & 1,21 & 3,89 \\
\hline
\end{tabular}

Tablo 2 incelendiğinde öğretmenlerin "mesleki sorumluluk" ortalamaları çok zayıf 1,548 $\pm 0,809$ (Min.=1; Mak.=4.9), "mesleki saygı" ortalamaları orta 3,016 $\pm 0,765$ (Min.=1.44; Mak.=5), "mesleki etik genel" ortalamaları zayıf

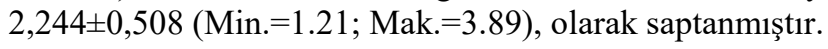

Tablo 3. Mesleki Motivasyon Puan Ortalamaları

\begin{tabular}{lccccc}
\hline & N & Ort & Ss & Min. & Mak. \\
\hline $\begin{array}{l}\text { Okul Ortamından } \\
\text { Kaynaklanan Motivasyon }\end{array}$ & 124 & 3,492 & 1,086 & 1,00 & 5,00 \\
\hline $\begin{array}{l}\text { Veli ve Öğrenciden } \\
\text { Kaynaklanan Motivasyon }\end{array}$ & 124 & 1,669 & 0,965 & 1,00 & 5,00 \\
\hline$\dot{\text { İçsel Motivasyon }}$ & 124 & 1,804 & 1,012 & 1,00 & 5,00 \\
\hline $\begin{array}{l}\text { Mesleki Motivasyon } \\
\text { Genel }\end{array}$ & 124 & 2,272 & 0,571 & 1,08 & 3,85 \\
\hline
\end{tabular}

Tablo 3 incelendiğinde öğretmenlerin "okul ortamından kaynaklanan motivasyon" ortalamaları yüksek 3,492 $\pm 1,086$ (Min.=1; Mak.=5), "veli ve öğrenciden kaynaklanan

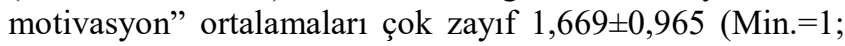
Mak.=5), "içsel motivasyon" ortalamaları zayıf 1,804 $\pm 1,012$ (Min.=1; Mak.=5), "mesleki motivasyon genel" ortalamaları 
zayıf 2,272 $\pm 0,571 \quad$ (Min.=1.08; Mak.=3.85), olarak

saptanmıştır.

Tablo 4. Mesleki Etik ve Mesleki Motivasyon Puanları Arasındaki Korelasyon Analizi

\begin{tabular}{|c|c|c|c|c|}
\hline & & Mesleki Sorumluluk & Mesleki Saygı & Mesleki Etik Genel \\
\hline \multirow{2}{*}{$\begin{array}{l}\text { Okul Ortamından } \\
\text { Motivasyon }\end{array}$} & \multirow{2}{*}{ Kaynaklanan } & $-0,206^{*}$ & $-0,074$ & $-0,225^{*}$ \\
\hline & & 0,022 & 0,415 & 0,012 \\
\hline \multirow{2}{*}{$\begin{array}{l}\text { Veli ve Öğrenciden Kaynaklanan } \\
\text { Motivasyon }\end{array}$} & $\mathrm{r}$ & $0,499 * *$ & 0,078 & $0,473 * *$ \\
\hline & $\mathrm{p}$ & 0,000 & 0,389 & 0,000 \\
\hline \multirow{2}{*}{ İçsel Motivasyon } & $\mathrm{r}$ & $\mathbf{0 , 3 7 8 * *}$ & 0,116 & $0,399 * *$ \\
\hline & $\mathrm{p}$ & 0,000 & 0,201 & 0,000 \\
\hline \multirow{2}{*}{ Mesleki Motivasyon Genel } & $\mathrm{r}$ & $0,410 * *$ & 0,071 & $0,394 * *$ \\
\hline & $\mathrm{p}$ & 0,000 & 0,436 & 0,000 \\
\hline
\end{tabular}

\section{$*<0,05 ; * *<0,01$}

Tablo 4 incelendiğinde mesleki sorumluluk, mesleki sayg1, mesleki etik genel, okul ortamından kaynaklanan motivasyon, veli ve öğrenciden kaynaklanan motivasyon, içsel motivasyon, mesleki motivasyon genel, arasındaki korelasyon analizlerine bakıldığında; okul ortamından kaynaklanan motivasyon ile mesleki sorumluluk arasında $\mathrm{r}=-0.206$ negatif $(\mathrm{p}=0,022<0.05)$, Okul ortamından kaynaklanan motivasyon ile mesleki etik genel arasında $\mathrm{r}=-$ 0.225 negatif $(p=0,012<0.05)$, Veli ve öğrenciden kaynaklanan motivasyon ile mesleki sorumluluk arasında $\mathrm{r}=0.499$ pozitif $(\mathrm{p}=0,000<0.05)$, Veli ve öğrenciden

Tablo 5. Mesleki Etiğin Mesleki Motivasyon Üzerine Etkisi kaynaklanan motivasyon ile mesleki etik genel arasında $\mathrm{r}=0.473$ pozitif $(\mathrm{p}=0,000<0.05)$, İçsel motivasyon ile mesleki sorumluluk arasında $\mathrm{r}=0.378$ pozitif $(\mathrm{p}=0,000<0.05)$, İçsel motivasyon ile mesleki etik genel arasinda $\mathrm{r}=0.399$ pozitif $\quad(\mathrm{p}=0,000<0.05), \quad$ Mesleki motivasyon genel ile mesleki sorumluluk arasinda $\mathrm{r}=0.41$ pozitif $(\mathrm{p}=0,000<0.05)$, Mesleki motivasyon genel ile mesleki etik genel arasında $\mathrm{r}=0.394$ pozitif $(\mathrm{p}=0,000<0.05)$ ilişki bulunmuştur. Diğer değişkenler arasındaki ilişkiler istatistiksel olarak anlamlı değildir $(\mathrm{p}>0.05)$.

\begin{tabular}{llllllll}
\hline Bağımlı Değişken & Bağımsız Değişken & B & t & p & F & Model (p) & $\mathbf{R}^{\mathbf{2}}$ \\
\hline \multirow{2}{*}{ Mesleki Motivasyon Genel } & Sabit & 1,279 & 5,952 & 0,000 & & 0,148 \\
& Mesleki Etik Genel & 0,442 & 4,735 & 0,000 & & & \\
& & & & & & & \\
& Sabit & 1,464 & 6,458 & 0,000 & & 0,000 & 0,176 \\
Mesleki Motivasyon Genel & Mesleki Sorumluluk & 0,308 & 5,247 & 0,000 & 14,137 & \\
& Mesleki Saygı & 0,110 & 1,768 & 0,080 & & \\
\hline
\end{tabular}

Tablo 5 incelendiğinde mesleki etik genel ile mesleki motivasyon genel arasındaki neden sonuç ilişkisini belirlemek üzere yapılan regresyon analizi anlamlı bulunmuştur $\quad(\mathrm{F}=22,420 ; \quad \mathrm{p}=0,000<0.05)$. Mesleki motivasyon genel düzeyindeki toplam değişim \%14.8 oranında mesleki etik genel tarafindan açıklanmaktadır $\left(\mathrm{R}^{2}=0,148\right)$. Mesleki etik genel mesleki motivasyon genel düzeyini arttırmaktadır $(\beta=0,442)$.
Mesleki sorumluluk, mesleki saygı ile mesleki motivasyon genel arasındaki neden sonuç ilişkisini belirlemek üzere yapılan regresyon analizi anlamlı bulunmuştur $(\mathrm{F}=14,137$; $\mathrm{p}=0,000<0.05)$. Mesleki motivasyon genel düzeyindeki toplam değişim \%17.6 oranında mesleki sorumluluk, mesleki saygı tarafından açıklanmaktadır $\left(\mathrm{R}^{2}=0,176\right)$. Mesleki sorumluluk mesleki motivasyon genel düzeyini arttırmaktadır $\quad(\beta=0,308) . \quad$ Mesleki sayg1 mesleki motivasyon genel düzeyini etkilememektedir $(\mathrm{p}=0.080>0.05)$. 
Tablo 6. Mesleki Etik Puanlarının Tanımlayıcı Özelliklere Göre Farklılaşma Durumu

\begin{tabular}{lllll}
\hline Demografik Özellikler & n & Mesleki Sorumluluk & Mesleki Saygı & Mesleki Etik Genel \\
\hline Cinsiyet & & Ort \pm SS & Ort \pm SS & Ort \pm SS \\
\cline { 2 - 5 } Kadın & 20 & $1,325 \pm 0,522$ & $3,144 \pm 0,784$ & $2,187 \pm 0,439$ \\
Erkek & 104 & $1,591 \pm 0,848$ & $2,992 \pm 0,762$ & $2,255 \pm 0,522$ \\
$\mathrm{t}=$ & & $-1,353$ & 0,818 & $-0,544$ \\
$\mathrm{p}=$ & & 0,178 & 0,415 & 0,587
\end{tabular}

\begin{tabular}{lllll}
\hline Yaş & & Ort \pm SS & Ort \pm SS & Ort \pm SS \\
\hline 30 ve Alt1 & 86 & $1,635 \pm 0,913$ & $3,078 \pm 0,812$ & $2,318 \pm 0,546$ \\
30 Üzeri & 38 & $1,353 \pm 0,453$ & $2,877 \pm 0,634$ & $2,075 \pm 0,363$ \\
$\mathrm{t}=$ & & 1,808 & 1,349 & 2,511 \\
$\mathrm{p}=$ & & $\mathbf{0 , 0 2 3}$ & 0,141 & $\mathbf{0 , 0 0 4}$
\end{tabular}

\begin{tabular}{|c|c|c|c|c|}
\hline Medeni Durum & & Ort $\pm \mathrm{SS}$ & Ort $\pm \mathrm{SS}$ & Ort $\pm \mathrm{SS}$ \\
\hline Evli & 67 & $1,582 \pm 0,770$ & $3,013 \pm 0,756$ & $2,260 \pm 0,496$ \\
\hline Bekar & 57 & $1,509 \pm 0,858$ & $3,020 \pm 0,782$ & $2,224 \pm 0,526$ \\
\hline $\mathrm{t}=$ & & 0,502 & $-0,045$ & 0,388 \\
\hline $\mathrm{p}=$ & & 0,617 & 0,964 & 0,699 \\
\hline
\end{tabular}

\begin{tabular}{lllll}
\hline Çalışılan Okul & & Ort \pm SS & Ort \pm SS & Ort \pm SS \\
\cline { 2 - 4 } İlköğretim & 81 & $1,512 \pm 0,729$ & $3,000 \pm 0,771$ & $2,217 \pm 0,478$ \\
Lise & 43 & $1,616 \pm 0,947$ & $3,047 \pm 0,762$ & $2,294 \pm 0,564$ \\
$\mathrm{t}=$ & & $-0,680$ & $-0,321$ & $-0,799$ \\
$\mathrm{p}=$ & & 0,498 & 0,749 & 0,426
\end{tabular}

\begin{tabular}{lllll}
\hline Öğretmenlik Kıdemi & & Ort \pm SS & Ort \pm SS & Ort \pm SS \\
\cline { 3 - 5 } 2 Y1l ve Altı & 46 & $1,704 \pm 0,939$ & $3,007 \pm 0,781$ & $2,322 \pm 0,569$ \\
3-5 Y1l & 52 & $1,431 \pm 0,714$ & $3,013 \pm 0,799$ & $2,180 \pm 0,476$ \\
6 Yil ve Üzeri & 26 & $1,508 \pm 0,718$ & $3,039 \pm 0,691$ & $2,233 \pm 0,455$ \\
F= & & 1,448 & 0,014 & 0,950 \\
p= & & 0,239 & 0,986 & 0,390
\end{tabular}

\begin{tabular}{lllll}
\hline İdari Görev Durumu & & Ort \pm SS & Ort \pm SS & Ort \pm SS \\
\cline { 2 - 5 } Evet & 24 & $1,763 \pm 1,046$ & $3,079 \pm 0,853$ & $2,386 \pm 0,646$ \\
Hayır & 100 & $1,497 \pm 0,738$ & $3,001 \pm 0,746$ & $2,210 \pm 0,467$ \\
$\mathrm{t}=$ & & 1,451 & 0,445 & 1,536 \\
$\mathrm{p}=$ & & 0,149 & 0,657 & 0,127
\end{tabular}

Tablo 6 incelendiğinde öğretmenlerin mesleki sorumluluk, mesleki sayg1, mesleki etik genel puanları cinsiyet değişkenine göre anlamlı farklılık göstermemektedir (p>0.05). 30 yaş ve altı olanların mesleki sorumluluk puanları $(\mathrm{x}=1,635), 30$ yaş üzeri olanların mesleki sorumluluk puanlarından $(\mathrm{x}=1,353)$ yüksek bulunmuştur $(\mathrm{t}=1,808 ; \mathrm{p}=0.023<0.05)$. Yaş 30 ve altı olanların mesleki etik genel puanları $(\mathrm{x}=2,318)$, yaş 30 üzeri olanların mesleki etik genel puanlarından $(\mathrm{x}=2,075)$ yüksek bulunmuştur $(\mathrm{t}=2,511 ; \mathrm{p}=0.004<0.05)$. Öğretmenlerin mesleki sayg1 puanları yaş değişkenine göre anlamlı farklılık göstermemektedir $\quad(p>0.05)$. Öğretmenlerin mesleki sorumluluk, mesleki sayg1, mesleki etik genel puanları medeni durum değişkenine göre anlamlı farklılık göstermemektedir $\quad(\mathrm{p}>0.05)$. Öğretmenlerin mesleki sorumluluk, mesleki saygı, mesleki etik genel puanları çalışılan okul değişkenine göre anlamlı farklılık göstermemektedir $\quad(p>0.05)$. Öğretmenlerin mesleki sorumluluk, mesleki sayg1, mesleki etik genel puanları öğretmenlik kıdemi değişkenine göre anlamlı farklılık göstermemektedir $\quad(p>0.05)$. Öğretmenlerin mesleki sorumluluk, mesleki sayg1, mesleki etik genel puanları idari görev durumu değişkenine göre anlamlı farklılık göstermemektedir ( $\mathrm{p}>0.05)$. 
Tablo 7. Mesleki Motivasyon Puanlarının Tanımlayıcı Özelliklere Göre Farklılaşma Durumu

\begin{tabular}{|c|c|c|c|c|c|}
\hline $\begin{array}{l}\text { Demografik } \\
\text { Özellikler }\end{array}$ & $\mathbf{n}$ & $\begin{array}{c}\text { Okul Ortamindan } \\
\text { Kaynaklanan } \\
\text { Motivasyon }\end{array}$ & $\begin{array}{c}\text { Veli ve Öğrenciden } \\
\text { Kaynaklanan Motivasyon }\end{array}$ & $\begin{array}{c}\text { İçsel } \\
\text { Motivasyon }\end{array}$ & $\begin{array}{c}\text { Mesleki } \\
\text { Motivasyon } \\
\text { Genel }\end{array}$ \\
\hline Cinsiyet & & Ort $\pm \mathrm{SS}$ & Ort $\pm \mathrm{SS}$ & Ort $\pm \mathrm{SS}$ & Ort \pm SS \\
\hline Kadın & 20 & $3,500 \pm 1,076$ & $1,480 \pm 0,976$ & $1,575 \pm 0,939$ & $2,131 \pm 0,532$ \\
\hline Erkek & 104 & $3,490 \pm 1,093$ & $1,706 \pm 0,963$ & $1,849 \pm 1,024$ & $2,299 \pm 0,576$ \\
\hline $\mathrm{t}=$ & & 0,036 & $-0,958$ & $-1,108$ & $-1,208$ \\
\hline $\mathrm{p}=$ & & 0,971 & 0,340 & 0,270 & 0,229 \\
\hline Yaş & & Ort \pm SS & Ort \pm SS & Ort \pm SS & Ort \pm SS \\
\hline 30 ve Alt1 & 86 & $3,486 \pm 1,079$ & $1,765 \pm 1,069$ & $1,863 \pm 1,031$ & $2,325 \pm 0,574$ \\
\hline 30 Üzeri & 38 & $3,507 \pm 1,116$ & $1,453 \pm 0,632$ & $1,671 \pm 0,969$ & $2,152 \pm 0,551$ \\
\hline $\mathrm{t}=$ & & $-0,099$ & 1,674 & 0,975 & 1,564 \\
\hline $\mathrm{p}=$ & & 0,921 & 0,045 & 0,331 & 0,120 \\
\hline
\end{tabular}

\begin{tabular}{|c|c|c|c|c|c|}
\hline Medeni Durum & & Ort $\pm \mathrm{SS}$ & Ort $\pm \mathrm{SS}$ & Ort $\pm \mathrm{SS}$ & Ort $\pm \mathrm{SS}$ \\
\hline Evli & 67 & $3,508 \pm 1,093$ & $1,645 \pm 0,885$ & $1,724 \pm 0,920$ & $2,242 \pm 0,577$ \\
\hline Bekar & 57 & $3,474 \pm 1,086$ & $1,698 \pm 1,059$ & $1,899 \pm 1,112$ & $2,306 \pm 0,566$ \\
\hline$t=$ & & 0,172 & $-0,306$ & $-0,960$ & $-0,622$ \\
\hline $\mathrm{p}=$ & & 0,864 & 0,760 & 0,339 & 0,535 \\
\hline
\end{tabular}

\begin{tabular}{|c|c|c|c|c|c|}
\hline Çalışılan Okul & & Ort \pm SS & Ort \pm SS & Ort \pm SS & Ort $\pm \mathrm{SS}$ \\
\hline İlköğretim & 81 & $3,469 \pm 1,080$ & $1,699 \pm 0,995$ & $1,694 \pm 0,940$ & $2,242 \pm 0,579$ \\
\hline Lise & 43 & $3,535 \pm 1,108$ & $1,614 \pm 0,915$ & $2,012 \pm 1,119$ & $2,327 \pm 0,558$ \\
\hline$t=$ & & $-0,320$ & 0,464 & $-1,673$ & $-0,790$ \\
\hline $\mathrm{p}=$ & & 0,750 & 0,643 & 0,097 & 0,431 \\
\hline
\end{tabular}

\begin{tabular}{llllll}
\hline $\begin{array}{l}\text { Öğgretmenlik } \\
\text { Kıdemi }\end{array}$ & & Ort \pm SS & Ort \pm SS & Ort \pm SS & Ort \pm SS \\
\cline { 2 - 6 } 2 Y1l ve Alt1 & 46 & $3,467 \pm 1,204$ & $1,883 \pm 1,081$ & $1,967 \pm 1,163$ & $2,396 \pm 0,577$ \\
3-5 Y1l & 52 & $3,601 \pm 1,027$ & $1,531 \pm 0,911$ & $1,668 \pm 0,910$ & $2,210 \pm 0,542$ \\
6 Y1l ve Üzeri & 26 & $3,317 \pm 0,991$ & $1,569 \pm 0,807$ & $1,789 \pm 0,913$ & $2,175 \pm 0,598$ \\
F= & & 0,606 & 1,823 & 1,071 & 1,799 \\
p= & & 0,547 & 0,166 & 0,346 & 0,170
\end{tabular}

\begin{tabular}{|c|c|c|c|c|c|}
\hline $\begin{array}{l}\text { İdari } \\
\text { Durumu }\end{array}$ & Görev & Ort $\pm \mathrm{SS}$ & Ort $\pm \mathrm{SS}$ & Ort $\pm \mathrm{SS}$ & Ort $\pm \mathrm{SS}$ \\
\hline Evet & 24 & $3,167 \pm 1,351$ & $2,008 \pm 1,256$ & $1,917 \pm 1,183$ & $2,337 \pm 0,697$ \\
\hline Hayır & 100 & $3,570 \pm 1,004$ & $1,588 \pm 0,870$ & $1,778 \pm 0,972$ & $2,256 \pm 0,539$ \\
\hline$t=$ & & $-1,646$ & 1,937 & 0,603 & 0,618 \\
\hline $\mathrm{p}=$ & & 0,180 & 0,132 & 0,548 & 0,538 \\
\hline
\end{tabular}

Tablo 7 incelendiğinde öğretmenlerin okul ortamından kaynaklanan motivasyon, veli ve öğrenciden kaynaklanan motivasyon, içsel motivasyon, mesleki motivasyon genel puanları cinsiyet değişkenine göre anlamlı farklılık göstermemektedir ( $p>0.05) .30$ yaş ve altı olanların veli ve öğrenciden kaynaklanan motivasyon puanları $(\mathrm{x}=1,765), 30$ yaş üzeri olanların veli ve öğrenciden kaynaklanan motivasyon puanlarından $(\mathrm{x}=1,453)$ yüksek bulunmuştur $(\mathrm{t}=1,674 ; \mathrm{p}=0.045<0.05)$. Öğretmenlerin okul ortamından kaynaklanan motivasyon, içsel motivasyon, mesleki motivasyon genel puanları yaş değişkenine göre anlamlı farklılık göstermemektedir $(\mathrm{p}>0.05)$. Öğretmenlerin okul ortamından kaynaklanan motivasyon, veli ve öğrenciden kaynaklanan motivasyon, içsel motivasyon, mesleki motivasyon genel puanları medeni durum değişkenine göre anlamlı farklılık göstermemektedir ( $>>0.05)$. Öğretmenlerin okul ortamından kaynaklanan motivasyon, veli ve öğrenciden kaynaklanan motivasyon, içsel motivasyon, mesleki motivasyon genel puanları çalışılan okul değişkenine göre anlamlı farklılık göstermemektedir (p>0.05). Öğretmenlerin okul ortamından kaynaklanan motivasyon, veli ve öğrenciden kaynaklanan motivasyon, içsel motivasyon, mesleki motivasyon genel puanları öğretmenlik kıdemi değişkenine göre anlamlı farklılık göstermemektedir ( $p>0.05$ ). Öğretmenlerin okul ortamından kaynaklanan motivasyon, veli ve öğrenciden kaynaklanan 
motivasyon, içsel motivasyon, mesleki motivasyon genel puanları idari görev durumu değişkenine göre anlamlı farklılık göstermemektedir ( $\mathrm{p}>0.05)$.

\section{Tartışma, Sonuç ve Öneriler}

Çalışmanın sonuçları doğrultusunda konuyla ilgili ya da yakın ilişkisi olan kaynaklara ulaşılmıştır (Fisher, 2013; Gözütok, 1999; Karaköse, \& Kocabaş, 2006; Mabagala, 2015; Ömür, \& Nartgün, 2013). Bu çalışmada mesleki etik puan ortalamaları incelendiğinde öğretmenlerin "mesleki sorumluluk" ortalamaları çok zayıf, "mesleki saygı" ortalamaları orta ve "mesleki etik genel" ortalamaları zayıf olarak saptanmıştır. Öğretmenlerin mesleki etik durumları ile ilgili yapılmış diğer çalışmalarda ise çalışmayla farklı olarak mesleki etik puanlarının orta ve yüksek düzeyde olduğu tespit edilmiştir (Mabagala, 2014; Özbek, 2003; Uğraş, 2018). Bu durum özellikle derslerin takibi ve amacina uygun işlenip işlenmediği, öğrenci ve veli arasındaki köprünün nasıl kurulduğu ve velilerin beden eğitimi ve spor derslerinden yüksek not beklentisi gibi sebeplerle ilişkili olabileceği düşünülmektedir.

$\mathrm{Bu}$ çalışmada mesleki motivasyon puan ortalamaları incelendiğinde öğretmenlerin "okul ortamından kaynaklanan motivasyon" ortalamaları yüksek, "veli ve öğrenciden kaynaklanan motivasyon" ortalamaları çok zayıf, "içsel motivasyon" ortalamaları zayıf ve "mesleki motivasyon genel" ortalamaları zayıf olarak saptanmıştır. Bu saptamaların velilerin öğrencileri takip noktasında spor kültürüne sahip olma durumlarından, yine velilerin beden eğitimi ve spor derslerini sıradan bir ders olarak görme durumlarından kaynaklandığına inanılmaktadır.

Mesleki motivasyon ile mesleki etik davranışlarını alt boyutlarının arasındaki ilişki ve mesleği etiğin mesleki motivasyon üzerindeki etkisine dair sonuçlara bakıldığında, Mesleki sorumluluk, mesleki saygi ile mesleki motivasyon genel arasındaki neden sonuç ilişkisini belirlemek üzere yapılan regresyon analizi anlamlı bulunmuştur. Mesleki sorumluluk mesleki motivasyon genel düzeyini arttırmaktadır. Mesleki saygı mesleki motivasyon genel düzeyini etkilememektedir. Ayrıca, Okul ortamından kaynaklanan motivasyon ile mesleki sorumluluk arasında $\mathrm{r}=$ 0.206 negatif, okul ortamından kaynaklanan motivasyon ile mesleki etik genel arasında $r=-0.225$ negatif, veli ve öğrenciden kaynaklanan motivasyon ile mesleki sorumluluk arasında $\mathrm{r}=0.499$ pozitif, veli ve öğrenciden kaynaklanan motivasyon ile mesleki etik genel arasında pozitif, içsel motivasyon ile mesleki sorumluluk arasında pozitif, içsel motivasyon ile mesleki etik genel arasında pozitif, mesleki motivasyon genel ile mesleki sorumluluk arasında pozitif, mesleki motivasyon genel ile mesleki etik genel arasında pozitif, ilişki bulunmuştur. Diğer değişkenler arasındaki ilişkiler istatistiksel olarak anlamlı değildir. Beden eğitimi ve spor öğretmenlerinin mesleki motivasyon ve mesleki etik davranışlarını alt boyutlarının ise, cinsiyet, yaş, medeni durum, çalışılan okul, öğretmenlik kıdemi ve idari görev durumu değişkenlerine göre farklılaşıp farklılaşmadığına baktığımızda; katılımcıların mesleki etik alt boyut puanlarının sadece yaş değişkeninde 30 yaş altı olanlar lehine anlamlı farklılık görülmüşken diğer değişkenlerde anlamlı farklılık görülmemiştir. Mesleki motivasyon ölçeği alt boyut puanlarında ise 30 yaş ve altı olanların veli ve öğrenciden kaynaklanan motivasyon puanlarının 30 yaş üzeri olanlara göre daha yüksek olduğu görülmüştür. Ancak çalışma sonucu, mesleki motivasyon ölçeği alt boyut puanlarının diğer değişkenlere göre anlamlı bir farklılık göstermemiştir.

Her öğretmenlik branşında olduğu gibi beden eğitimi ve spor öğretmeninin sorumlulukları da ders saatleri ile sınırlı kalmamaktadır. Öğrenciler ile ders dışında yapılan çalışmaların yanında yöneticiler, diğer öğretmenler ve toplum ile ilişkiler ile de meşgul olan beden eğitimi ve spor öğretmenleri, bu sorumluluklar için günlük çalışmalarından daha fazla zamana ihtiyaç duyarlar (Altuntaş, 2016). Çalışmada yaş değişkeninde anlamlı farkın ortaya çıkması 30 yaş altı bireylerin üniversiteden mezun olup meslek hayatlarına yeni başladığı düşünüldüğünden, kariyerin başında yüksek bir motivasyonla görev yapabilecekleri ve henüz meslek içerisindeki olumsuzluklarla karşılaşmadıklarından dolayı öğrenci ve velilerden kaynaklanan motivasyon ve mesleki sorumluluklarının 30 yaş üstü bireylerden yüksek çıkmasının sebebi olarak düşünülmektedir. Ayrıca bu sonuçla birlikte, yaş ilerledikçe mesleğin olumsuz taraflarının görülmesinden dolayı motivasyonun düşeceğini söylemek mümkün olacaktır. Alan yazında öğretmenliğin ilk yılında çalışan farklı branş öğretmenlerinin de etik algılama düzeylerinin olumlu bir şekilde arttığını belirten çalışmalar görülmüştür (Özen, 2017; Sakin, 2007).

Diğer taraftan cinsiyet, medeni durum, öğretmenlik kıdemi ve idari görev durumu değişkenlerinde farkın çıkmaması özellikle içsel motivasyon kaynağının kendi iyiliği için ya da deneyimlerinden elde ettiği haz ve memnuniyet için bir aktiviteye katılımını veya devam ettirmeyi ifade ettiğinden (Lee, 2005) kıdem veya idari görev gibi dışsal motivasyonların bu değişkenlere göre değişmeyeceği sonucunu destekler niteliktedir. Alan yazında mesleki etiğin ve mesleki motivasyonun cinsiyet değişkenine göre anlamlı farklılık olmadığı yönünde bu çalışmanın sonucuna paralellik gösteren çalışmalar mevcuttur (Argon, \& Ertürk, 2013; Çelebi, 2012; Dolaşır, 2009; Özbek, 2003; Recepoğlu, 2013; Toprakç1, 2010). Diğer taraftan kadınlar lehine çalışmaya tezat sonuçlar görülmüştür (Altınkurt, \& Yılmaz, 2011; Doğaner, \& Özbek, 2019). Bu durum genel anlamda ülkemizin eğitim sistemi içerisinde kadın ve erkek arasındaki eşitlik, üniversitelerin bütün öğretmenlik branşlarına sunmuş olduğu pedagojik formasyon eğitim durumu, mesleki etik ve mesleki motivasyon üzerinde bariz farklar ortaya koymadığını fakat bazı üniversitelerin eğitim sistemlerinde sunmuş oldukları pozitif farklılıklar yetiştirdikleri bireylerde de daha farklı sonuçlar ortaya koyabileceği düşünülmektedir.

Alan yazında, mesleki motivasyon ile mesleki etik ilişkisine ait bulguda Uğraş'ın (2018) yapmış olduğu 'Beden Eğitimi ve Spor Öğretmenlerinin Mesleki Etik ve Mesleki Motivasyon Durumlarının Değerlendirilmesi" adlı tez çalışmasının analiz sonuçlarına göre "Okul Ortamından Kaynaklanan Motivasyon" ile "Mesleki sorumluluk" boyutları arasında negatif yönde anlamlı ilişki çıkarken "Mesleki Saygı" boyutu ile pozitif anlamlı bir ilişki olduğu tespit edilmiştir. "Veli ve Öğrenciden Kaynaklanan Motivasyon" ile "Mesleki Sorumluluk" ve "Genel Etik" boyutları arasında pozitif yönde anlamlı bir ilişki olduğu belirlenmiştir. Beden eğitimi ve spor öğretmenlerinin "İçsel Motivasyon" boyutu ile "Mesleki Sorumluluk" ve "Genel Etik" arasında pozitif yönde anlamlı bir ilişki olduğu 
saptanmıştır. Beden eğitimi ve spor öğretmenlerinin "Genel Motivasyonları" ile "Mesleki Sorumluluk", "Mesleki Sayg1 ve "Genel Etik" düzeyleri arasında pozitif yönde anlamlı bir ilişki olduğu saptanmıştır. Bu araştırmada da mesleki etik ve mesleki motivasyon alt boyutlar arasında pozitif ve negatif ilişkilerin paralellik göstermesi çalışmayı desteklenmektedir.

Beden eğitimi ve spor öğretmenlerinin derslerini işlerken gerekli imkanlara sahip olamamaları, derslerin işleyişinde birtakım zorlukları beraberinde getirmektedir. Okul ortamından kaynaklanan bu zorluklar motivasyonlarının düşmesinin yanı sıra mesleki sorumluluk etiğine de olumsuz etki yapmış olabileceği şeklinde yorumlanabilir (Uğraş, 2018). Uygulayıcılara yönelik özellikle sosyal yaşam imkanlarının kısıtlı olduğu yerlerde öğretmenlerin kültür ve sanat gibi sosyal faaliyetlerde de bulunmaları önerilmektedir. $\mathrm{Bu}$ çerçevede ayrıca araştırmacılara şu önerilerde bulunulabilir:

Beden eğitimi ve spor öğretmenleri olarak örneklemi belirlenen bu araştırma; farklı yaş grupları, farklı öğretmenlik branşları ve farklı meslek grupları üzerinden veri toplanarak farklı şehirlerde ve ilçelerde de yürütülebilir.

Beden eğitimi derslerinin sürdürülebilmesi için olmazsa olmaz spor salonu, açık spor tesisleri, spor branşına özgü top, raket, ayakkabı vb. imkanlarının kısıtlı olmasının, mesleki etik ve mesleki motivasyon durumlarını olumsuz etkileyebileceği düşünülmektedir. Bu bağlamda özellikle her türlü fiziki şartlara sahip okullarda görev yapan beden eğitimi ve spor öğretmenleri üzerinden de çalışmalar yap1labilir.

Beden eğitimi ve spor öğretmenlerinin mesleki etik ve mesleki motivasyon durumlarında yaşanan olumsuz tutumlarının görüşme ve gözlem teknikleriyle sebepleri detaylı olarak incelenerek nitel çalışmalar gerçekleştirilebilir.

\section{Kaynakça}

Altınkurt, Y., \& Yılmaz, K. (2011). Öğretmen adaylarının öğretmenlerin mesleki etik dışı davranışlar ile ilgili görüşleri. Mehmet Akif Ersoy Üniversitesi Eğitim Fakültesi Dergisi, 1(22), 113-128.

Altuntaş, E. A. (2016). Beden ĕgitimi öğretmeni adaylarının ögretmenlik mesleğine ilişkin tutumlart ile öz yeterlikleri arasındaki ilişki (Yüksek Lisans Tezi). Yükseköğretim Kurulu Ulusal Tez Merkezi'nden edinilmiştir (Tez No. 440790)

Amrai, K., Motlagh, S. E., Zalani, H. A., \& Parhon, H. (2011). The relationship between academic motivation and academic achievement students. Procedia-Social and Behavioral Sciences, 15(1), 399-402. doi.10.1016/j.sbspro.2011.03.111

Argon, T., \& Ertürk, R. (2013). İlköğretim okulu öğretmenlerinin içsel motivasyonları ve örgütsel kimliğe yönelik alg1ları. Kuram ve Uygulamada Ĕgitim Yönetimi Dergisi, 19(2), 159-179.

Aygün, M. (2019). Buz hokeyi sporcularında duygusal zekâ ve liderlik. Ankara: Nobel Yayınları.
Ayık, A., \& Ataş, Ö. (2014). Öğretmen adaylarının öğretmenlik mesleğine yönelik tutumları ile öğretme motivasyonları arasındaki ilişki. Ĕgitim Bilimleri Araştırmaları Dergisi, $\quad 4(1), \quad 25-43$. doi.10.12973/jesr.2014.41.2

Bayrak, E., Çınar, V., Çoban, B., \& Çoşkuner, Z. (2013). Beden eğitimi ve spor yüksekokulu öğretmen adayları ile eğitim fakültesi öğretmen adaylarının bilimsel epistemolojik inançlarının farklı değişkenler açısından incelenmesi. International Journal of Social Science, 6(2), 1817-1828.

Brouse, C. H., Basch, C. E., LeBlanc, M., McKnight, K. R., \& Lei, T. (2010). College students' academic motivation: Differences by gender, class, and source of payment. College Quarterly, 13(1), 1-10.

Cevizci, A. (2002). Etiğe giriş. İstanbul: Engin Yayıncılık.

Çelebi, N., \& Akbağ, M. (2012). Genel liselerde çalışan öğretmenlerin etik davranışlarını belirlemeye yönelik bir araştırma. International Online Journal of Educational Sciences, 4(2), 425-41.

Doğaner, S., \& Özbek, O. (2019). Beden eğitimi öğretmeni adaylarının mesleki etik ilkelere ve öğretmenliğe yönelik tutumlarına ilişkin görüşleri. Spormetre Dergisi, 17(1), 197-208.

Dolaşır, T. S., \& Büyüköztürk, Ş. (2009). Antrenörlerin mesleki etik ilkeleri nelerdir? Nasıl ölçülür? Ölçek geliştirme: ölçeğin geçerlik ve güvenirliği. Spormetre Dergisi, $\quad 7(4), \quad$ 159-68. doi.10.1501/Sporm_0000000166

Eroğlu, E. (2019). Beden eğitimi ve spor bilimlerinin temelleri. Ankara: Akademisyen Yayınevi.

Eroğlu, E., \& Ersoy, A. (2019). Beden eğitimi ve spor yüksekokulu öğrencilerinin bazı değişkenlere göre öğrenilmiş güçlülük düzeylerinin incelenmesi. Uluslararası Multidisipliner Akademik Araştırmalar Dergisi, 6(2), 68-75.

Eroğlu, S. Y., \& Acet, M. (2017). İşitme engelli öğrencilerin spor yapma değişkenine göre sosyal görünüş kaygısı ile yaşam kalitesi düzeylerinin incelenmesi. Türkiye Klinikleri Spor Bilimleri Dergisi, 9(2), 65-70. doi.10.5336/sportsci.2016-54033

Fisher, Y. (2013). Exploration of values: 1sraeli teachers' professional ethics. Social Psychology of Education, 16(1), 297-315.

Gözütok, F. D. (1999). Öğretmenlerin etik davranışları. Ankara Üniversitesi Eğitim Bilimleri Fakültesi Dergisi, 32(1-2), 83-99.

Gratton, C., \& Jones, I. (2010). Research methods for sports studies. UK: Routledge.

Karaköse, T, \& Kocabaş, İ. (2006). Özel ve devlet okullarında öğretmenlerin beklentilerinin iş doyumu ve motivasyon üzerine etkileri. Eğitimde Kuram ve Uygulama Dergisi, 2(1), 3-14.

Karasar, N. (2005). Bilimsel araştırma yöntemleri. Ankara: Nobel Yayınları. 
Karasar, N. (2011). Bilimsel araştırma yöntemleri. Ankara: Nobel Yayınları.

Kızılet, T. (2010). Drama ve diksiyon öğretiminin spor eğitimcisi adayı öğrencilerin mesleki yeterliliklerine etkisi (Yüksek Lisans Tezi). Yükseköğretim Kurulu Ulusal Tez Merkezi'nden edinilmiştir (Tez No. 523386).

Kiremitçi, O., Boz, B., \& Yıldız, L. (2018). Öğretmenlik mesleği ve alan seçimi motivasyonlart: beden ĕgitimi ögretmen adayları üzerine bir inceleme. 5. Uluslararası Multidisipliner Çalışmaları Kongresi, (s.1-10). Antalya: Ekim.

Lee, E. (2005). The relationship of motivation and flow experience to academic procrastination in university students. The Journal of Genetic Psychology, 166(1), 5-15. doi.10.3200/GNTP.166.1.5-15

Mabagala, S. (2014). The influence of physical education teachers' demographic variables on compliance with the professional code of ethics and conduct in tanzania. Journal of Physical Education And Sport, 2(14), 619. 625.

Mabagala, S. (2015). Students' perceptions on physical education teachers' compliance with the professional code of ethics and conduct in Tanzania. African Journal of Teacher Education, 4(2), 14-23.

Murathan, T. (2018). Spor sektöründe bilişim teknolojilerinin kullanımı. 3. Uluslararası Mesleki ve Teknik Bilimler Kongresi, (s.1547-1551). Gaziantep: Haziran.

Murathan, T., \& Özdemir, K. (2017). Investigation of the attitudes of physical education teacher candidates toward teaching profession and sense of competence in terms of some variables. Journal of Education and Learning, 6(4), 229-238. doi.10.5539/jel.v6n4p229
Ömür, Y. E., \& Nartgün, Ş. S. (2013). Öğretmen adaylarının öğretmenlik mesleğine ilişkin tutumları ile güdülenme düzeyleri arasındaki ilişki. Eğitimde Politika Analizi Dergisi, 2(2), 41-55.

Özbek, O. (2003). Beden eğitimi öğretmenlerinin meslekî etik ilkeleri ve bu ilkelere uyma düzeyleri (Doktora Tezi). Yükseköğretim Kurulu Ulusal Tez Merkezi'nden edinilmiştir (Tez No. 127829).

Özen, F. (2017). Sınıf öğretmenlerinin ve sınıf öğretmeni adayı öğrencilerin zamanla öğretmenlik meslek etiği algılarındaki değişim. Uluslararası Toplum Araştırmalart Dergisi, 7(13), 379-398. doi.10.26466/opus.331158

Recepoğlu, E. (2013). Öğretmenlerin iş motivasyonlarının farklı değişkenler açısından incelemesi. Kastamonu Ĕ̈itim Dergisi, 21(2), 575-88.

Sakin, A. (2007). Okul öncesi ögrretmenlerinin mesleki etik davranışlar hakkındaki görüşleri ile ahlaki yargl düzeyleri ve öğretmenlik tutumlarının incelenmesi (Doktora Tezi). Yükseköğretim Kurulu Ulusal Tez Merkezi'nden edinilmiştir (Tez No. 210313).

Toprakçı, E., Bozpolat E., \& Buldur, S. (2010). Öğretmen davranışlarının kamu meslek etiği ilkelerine uygunluğu. E-Uluslararası Eğitim Araştırmalart Dergisi, 1(2), 35-50.

Uğraş, S. (2018). Beden eğitimi ve spor öğretmenlerinin mesleki etik ve mesleki motivasyon durumlarının değerlendirilmesi (Doktora Tezi). Yükseköğretim Kurulu Ulusal Tez Merkezi'nden edinilmiştir (Tez No. 505875).

Zeynel, E., \& Çarıkçı, İ. H. (2015). Mesleki motivasyonun, iş tatmini ve örgütsel bağlılık üzerine etkisi: Akademisyenler üzerine bir araştırma. Süleyman Demirel Üniversitesi İktisadi ve İdari Bilimler Fakültesi Dergisi, 20(3), 217-248. 
EK 1: Etik Kurul Onay1

Evrak Tarih ve Sayısı: 02/03/2020-E.3495

T.C.

MUS ALPARSLAN ÜNIVERSITESI

BILLIMSEL ARAȘTIRMA VE YAYTN ETIGGI KURULU

\begin{tabular}{|l|l|l|}
\hline Toplantı Tarihi: 02/03/2020 & Toplant Sayısı: 3 & Karar Sayss: 20 \\
\hline
\end{tabular}

Bilimsel Araștırma ve Yayın Etiği Kurulu, Prof. Dr. Cevad SEL.AM başkanlığında toplanarak aşağıdaki kararları almıștır.

KARAR-7: Beden Eğitimi ve Spor Yülksekolulu Müdürlüğünün 17/02/2020 tarihli ve E.2529 sayıll yazıs1 olundu ve elleri incelendi.

Yap1lan incelemeler sonucunda; Üniversitemiz Beden Eğitimi ve Spor Yüksekokulu Beden Eğitimi ve Spor Eğitimi Bölümiı Beden Eğitimi ve Spor Eğitimi Anabilim Dalında görev yapmakta olan Dr. Öğr. Üyesi Metin KARAYOL'un 'Beden Egitimi ve Spor Öğretmenlerinin Mesleki Etik ile Mesleki Motivasyonlannın Incelenmesi" isimli makalesi Bilimsel Araştırma ve Yayın Etiği Kurulu tarafindan uygun görülmüş olup, durumun Beden Eğitimi ve Spor Yüksekokulu Müdürlüğüne bildirilmesine,

Oy birliği ile karar verildi.

BAȘKAN

Prof. Dr. Cevad SELAM

Rektör Yardumcisı

\begin{tabular}{|c|c|c|}
\hline ÜYE & ÜYE & ŨYE \\
\hline $\begin{array}{c}\text { Prof. Dr. Harun POLAT } \\
\text { Fen Edebiyat Fakültesi Öğr. Üvesi }\end{array}$ & $\begin{array}{l}\text { Doç. Dr. Hanifi KöRKOCA } \\
\text { SBF Ögr. Üyesi }\end{array}$ & $\begin{array}{c}\text { Dr. Ögrr. Üyesi Hasan TASALI } \\
\text { SBF Ögr. Üyesi }\end{array}$ \\
\hline ÜYE & UYE & ÜYE \\
\hline $\begin{array}{l}\text { Dr. Ögr. Üyesi Recep YILMAZ } \\
\text { IIF Ögr. Üyesi }\end{array}$ & $\begin{array}{l}\text { Dr, Öğr. Üyesi Mehmet SAILMAZZEM } \\
\text { Islami Îlimler Fakültesi Öğr. Üyesi }\end{array}$ & $\begin{array}{l}\text { Dr. Öğr. Üyesi Demet DENIZ } \\
\text { YILMAZ } \\
\text { Ëgitim Fakültesi Ögr. Üyesi }\end{array}$ \\
\hline ÜYE & ÜYE & \\
\hline $\begin{array}{l}\text { Dr. Ögr. Üyesi Sedat KARDAS } \\
\text { Fen Edebiyat Fakültesi Ögr. Ũyesi }\end{array}$ & $\begin{array}{c}\text { Dr. Ögr. Üyesi Bünyamin SARIKAYA } \\
\text { Egitim Fakültesi Ögr. Üyesi }\end{array}$ & \\
\hline
\end{tabular}

